\title{
Optimizing the removal of methylene blue from aqueous solutions using persulfate activated with nanoscale zero valent iron (nZVI) supported by reduced expanded graphene oxide (rEGO)
}

\author{
Alaa Mohamad Soubh ${ }^{1^{\circledR}}$, Mohammad Ali Abdoli ${ }^{1}{ }^{\mathbb{D}}$, Lorin Ali Ahmad ${ }^{(\mathbb{D}}$ \\ ${ }^{1}$ School of Environment, College of Engineering, University of Tehran, Tehran, Iran \\ ${ }^{2}$ Tartus Research Center, General Commission for Scientific Agriculture Research (GCSAR), Damascus, Syria
}

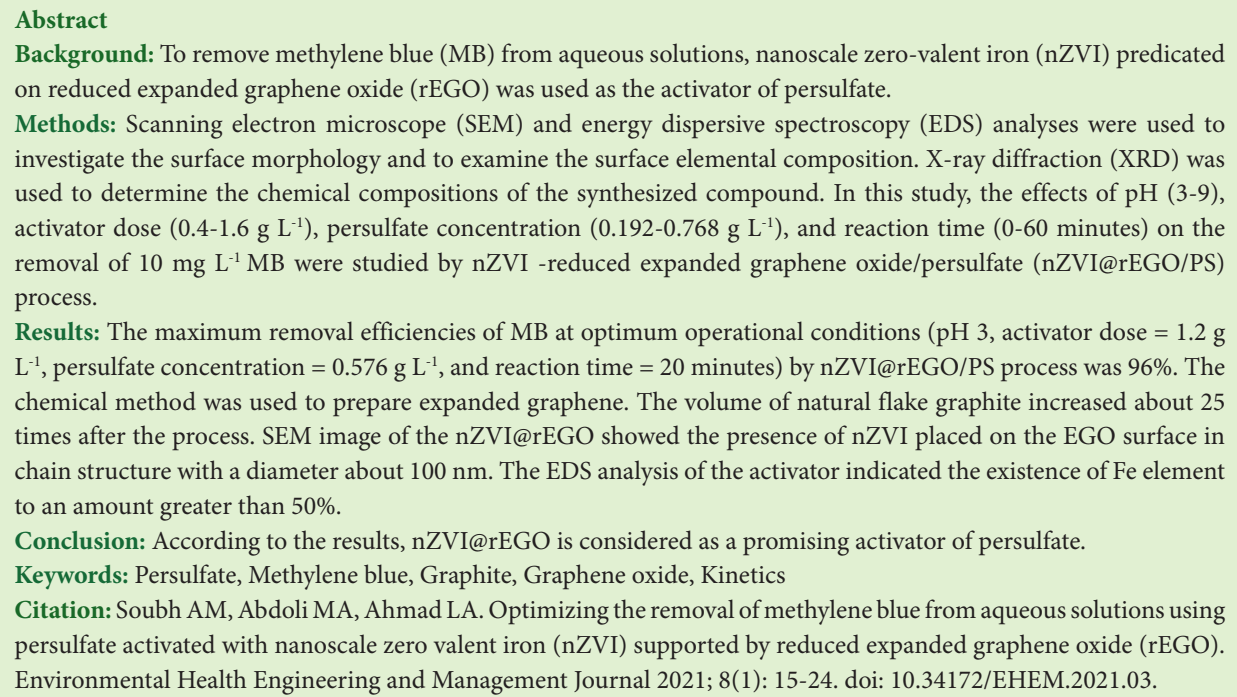

Article History:

Received: 9 September 2020 Accepted: 4 November 2020 ePublished: 31 January 2021

\section{Introduction}

The colored wastewater produced by industrial activities, such as textile industry and color production, has toxic effects on aquatic ecosystems (1). The presence of aromatic rings in the structure of azo dyes has increased the toxicity of these compounds and decreased their biodegradability (2). Dyes are among the most dangerous chemical compounds that can interfere with the process of photosynthesis in water resources. Methylene blue (MB) with molecular formula of $\mathrm{C}_{16} \mathrm{H}_{18} \mathrm{ClN}_{3} \mathrm{~S}$ and with molar mass of $319.85 \mathrm{~g} / \mathrm{mol}$ is one of the azo-cationic dyes $(3,4)$. Its chemical structure is shown in Figure 1. It is also used in various industries, such as textile, paper paints, hair color, etc. Intense exposure to MB leads to severe damages to the human body $(2,5)$. MB belongs to azo dyes family which contain the functional group $\mathrm{R}-\mathrm{N}=\mathrm{N}-\mathrm{R}^{\prime}$ in their structure and constitute a very large group of all coloring agents used. Azo dyes are a triggering factor for histamine, which may exacerbate the symptoms of asthma, and cause uterine contractions in pregnant women, resulting in miscarriage. Additionally, in combination with benzoates, they can cause hyperactivity in children. Even for nonallergic persons, they may be the cause of, for example, urticaria (6). Therefore, due to environmental problems and human health, treatment of wastewater containing these compounds has become a vital issue (5).

The activation of persulfate $\left(\mathrm{S}_{2} \mathrm{O}_{8}{ }^{2-}, \mathrm{E}^{\circ}=2.01 \mathrm{~V}\right)$ has attracted the interest of many researchers especially in the fields associated with the removal of pollutants (79). Activation of persulfate (PS) leads to the generation of sulfate radical (SR, $\left.\mathrm{SO}_{4}{ }^{--}, \mathrm{E}^{\circ}=2.5-3.1 \mathrm{~V}\right)$. Many studies have confirmed the effectiveness of SR on degradation of refractory pollutants $(10,11)$. Recently, many studies have indicated that zero-valent iron (ZVI) can be used as a suitable heterogeneous activator of PS $(12,13)$. ZVI is converted to $\mathrm{Fe}^{+2}$ according to several mechanisms: (1) Through its interaction with hydrogen ion $\left(\mathrm{H}^{+}\right)$(Eq. 1); (2) Interaction with PS ions (Eq. 2); (3) Interaction with 


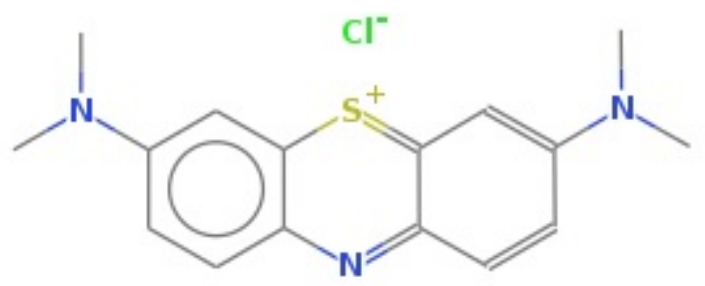

Figure 1. Chemical structure of methylene blue.

$\mathrm{O}_{2}$ and $\mathrm{H}_{2} \mathrm{O}$ in the aqueous solution (Eqs. 3 and 4); (4) Recovery interaction with $\mathrm{Fe}^{+3}$ (Eq. 5) (14-16). The $\mathrm{Fe}^{+2}$ ions activate PS according to Eq. (6).

$$
\begin{aligned}
& \mathrm{Fe}^{o}+2 \mathrm{H}^{+} \rightarrow \mathrm{Fe}^{2+}+\mathrm{H}_{2} \\
& \mathrm{Fe}^{o}+\mathrm{S}_{2} \mathrm{O}_{8}^{2-} \rightarrow \mathrm{Fe}^{2+}+2 \mathrm{SO}_{4}{ }^{2-} \\
& 2 \mathrm{Fe}^{\mathrm{o}}+\mathrm{O}_{2}+2 \mathrm{H}_{2} \mathrm{O} \rightarrow 2 \mathrm{Fe}^{2+}+4 \mathrm{OH}^{-} \\
& 2 \mathrm{Fe}^{o}+2 \mathrm{H}_{2} \mathrm{O} \rightarrow \mathrm{Fe}^{2+}+2 \mathrm{OH}^{-}+\mathrm{H}_{2} \\
& 2 \mathrm{Fe}^{3+}+\mathrm{Fe}^{o} \rightarrow 3 \mathrm{Fe}^{2+} \\
& \mathrm{S}_{2} \mathrm{O}_{8}{ }^{2-}+\mathrm{Fe}^{2+} \rightarrow \mathrm{SO}_{4}{ }^{--}+\mathrm{SO}_{4}{ }^{2-}+\mathrm{Fe}^{3+}
\end{aligned}
$$

Nanoscale ZVI (nZVI) has a higher surface area leading to more efficient results of activating PS $(17,18)$. Bare nZVI tends to be agglomerated and oxidized, which reduces its efficiency $(19,20)$. This disadvantage of nZVI can be prevented by supporting and dispersing nanoparticles on solid materials (21), such as resin (22), kaolinite (23), biochar (24), chitosan/silica (25), carbon (26), and graphene (27).

Graphene has a two-dimensional structure and a suitable surface area that make it a pre-eminent nanoparticle carrier $(28,29)$. The reduction of graphene oxide (GO) improves the performance of graphene when used as a nanoparticle carrier (30). For example, reduced graphene oxide-supported nanoparticles contributed to preventing the aggregation (31). Furthermore, expanded graphene oxide (EGO) with high quality and large surface area is suitable for environmental applications (32). Composites of nZVI with reduced graphene oxide (rGO) achieved the desired results in the removal of contaminants, such as $\mathrm{Pb}(\mathrm{II})$ (33), $\mathrm{As}(\mathrm{III}), \mathrm{As}(\mathrm{V})$ (34), and $\mathrm{Cd}(\mathrm{II})$ (35). Ahmad et al reported nZVI-rGO as an excellent and efficient persulfate activator than unsupported nZVI for degradation of trichloroethylene (36). EGO is a graphite derivative by chemical expansion of natural flake graphite. EGO has lower mobility in the porous media compared to GO. This feature makes it an environmentally friendly material. Recently, Dong et al have suggested a chemical method for the expansion of graphite as a pretreatment step for the synthesis of EGO. The expansion of graphite layers results in the fast diffusion of oxidant between layers even at low concentrations; as a result, the oxidation process is performed at room temperature. Furthermore, EGO with high quality and high surface area is suitable for environmental applications (32).

In this study, EGO was prepared by the chemically expanded graphite. Reduced EGO (rEGO) was used as a bed for the immobilization of nZVI. The nZVI@ rEGO was used as the activator of PS to remove MB from aqueous solutions. Moreover, the effects of essential factors affecting the performance of PS/nZVI@rEGO process, such as pH, nZVI@rEGO dose, PS dosage, contact time, and temperature were evaluated.

\section{Materials and Methods \\ Materials}

Natural flake graphite (NFG) (100-mesh) was obtained from Yantai Lushun Huitong Biotechnology (Yantai, China). $\mathrm{C}_{16} \mathrm{H}_{18} \mathrm{~N}_{3} \mathrm{SCl}(\geq 97 \%), \mathrm{Na}_{2} \mathrm{~S}_{2} \mathrm{O}_{8}$ (99\%), $\mathrm{CrO}_{3}(98 \%)$, $\mathrm{KMnO}_{4}(99 \%), \mathrm{KI}(99 \%)$, and $\mathrm{NaBH} 4$ (97\%) were obtained from Loba-Chemie (Mumbai, India). $\mathrm{FeSO}_{4} \cdot 7 \mathrm{H}_{2} \mathrm{O}$ (99.5\%), $\mathrm{NaOH}$ ( $\geq 97.0 \%), \mathrm{HCl}(37 \%), \mathrm{H}_{2} \mathrm{SO}_{4}$ (98\%), and $\mathrm{H}_{2} \mathrm{O}_{2}(30 \%)$ were purchased from Merck Company. Deionized water was used for the preparation of aqueous solutions.

\section{Synthesis of rEGO-supported $n Z V I$}

At first, expanded graphite (EG) was papered by mixing $1 \mathrm{~g}$ of $\mathrm{NFG}, 8.5 \mathrm{~g}$ of $\mathrm{CrO}_{3}$, and $70 \mathrm{~mL}$ of $\mathrm{HCl}$ for 2 hours. In order to remove the remaining $\mathrm{CrO}_{3}$, the prepared $\mathrm{EG}$ was soaked in distilled water 4 consecutive times. To complete the chemical expansion reactions, the resulted EG was submerged in $40 \mathrm{~mL}$ of $\mathrm{H}_{2} \mathrm{O}_{2}$ for 20 hours. Then, the EG was washed with distilled water and ethanol 4 consecutive times (32). The previous stage can be explained through the following equations: The presence of $\mathrm{CrO}_{3}$ and $\mathrm{HCl}$ together leads to the production of $\mathrm{CrO}_{2} \mathrm{Cl}_{2}$ between graphite layers (Eq. 7), the penetration stage. Adding $\mathrm{H}_{2} \mathrm{O}_{2}$ to the penetrated EG leads to the hydrolysis of $\mathrm{CrO}_{2} \mathrm{Cl}_{2}$ to $\mathrm{CrO}_{5}$ at acidic condition (Eqs. 8 and 9). The generated $\mathrm{CrO}_{5}$ interacts with $\mathrm{H}_{2} \mathrm{O}_{2}$ and oxygen gas is released between graphite layers which leads to its expansion (Eq. $10)$, the expansion stage $(37,38)$. As shown in Figure $2 a$, it almost doubled in size to 25 times.

$$
\begin{aligned}
& \mathrm{CrO}_{3}+2 \mathrm{HCl} \rightarrow \mathrm{CrO}_{2} \mathrm{Cl}_{2}+\mathrm{H}_{2} \mathrm{O} \\
& 2 \mathrm{CrO}_{2} \mathrm{Cl}_{2}+3 \mathrm{H}_{2} \mathrm{O} \rightarrow \mathrm{H}_{2} \mathrm{Cr}_{2} \mathrm{O}_{7}+4 \mathrm{HCl} \\
& \mathrm{Cr}_{2} \mathrm{O}_{7}^{-2}+2 \mathrm{H}^{+}+4 \mathrm{H}_{2} \mathrm{O} \rightarrow 2 \mathrm{CrO}_{5}+5 \mathrm{H}_{2} \mathrm{O} \\
& 2 \mathrm{CrO}_{5}+6 \mathrm{H}^{+}+7 \mathrm{H}_{2} \mathrm{O}_{2} \rightarrow 2 \mathrm{Cr}^{3+}+10 \mathrm{H}_{2} \mathrm{O}_{2}+7 \mathrm{O}_{2} \uparrow
\end{aligned}
$$

Before starting the oxidation process, the EG was soaked in $\mathrm{H}_{2} \mathrm{SO}_{4}$ to eliminate the remained internal $\mathrm{H}_{2} \mathrm{O}$ between graphite layers for 10 minutes. Then, $2 \mathrm{~g}$ of $\mathrm{KMnO}_{4}$ was mixed with $20 \mathrm{~mL}$ of $\mathrm{H}_{2} \mathrm{SO}_{4}$ in an ice bath for 30 minutes. After that, the mixture was removed from 


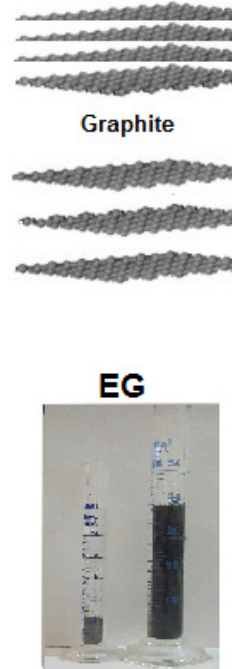

(a)
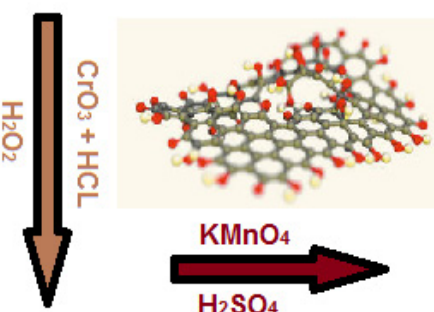

$\mathrm{H}_{2} \mathrm{SO}_{4}$

EGO

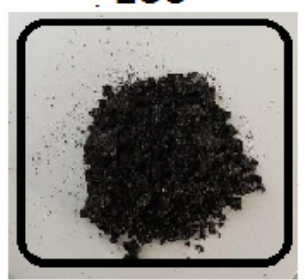

(b)

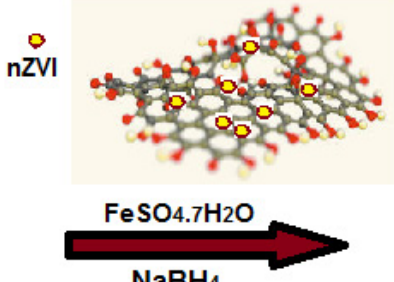

$\mathrm{NaBH}_{4}$

nZVI@rEGo

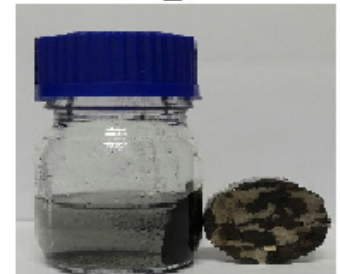

(c)

Figure 2. Preparation of (a) EG, (b) EGO, and (c) nZVI@rEGO

ice bath and it was leaved without mechanical mixing for 4 hours. Afterwards, the EG was added to the mixture and it was leaved for 2 hours to generate EGO. To complete the oxidation process, the produced EGO was soaked in diluted $\mathrm{H}_{2} \mathrm{O}_{2}$ solution and cooled in an ice bath. Then, the EGO was washed with distilled water and ethanol 4 consecutive times (32). Figure $2 \mathrm{~b}$ shows the mechanism of oxidation process.

To predicate nZVI on EGO, Fan et al. method was used (33). For this purpose, $1 \mathrm{~g}$ of EGO was scattered in distilled water for 2 hours and $5 \mathrm{~g}$ of $\mathrm{FeSO}_{4} 7 \mathrm{H}_{2} \mathrm{O}$ was mixed in $50 \mathrm{~mL}$ of distilled water, then, it was added to the suspended EGO where mixing was continued for 12 hours. The reducing solution was prepared by dissolving $1.4 \mathrm{~g}$ of $\mathrm{NaBH}_{4}$ as a reducing agent in $50 \mathrm{~mL}$ of distilled water. Then, it was slowly added to the previous mixture where $\mathrm{Fe}^{+2}$ was converted to nZVI according to Eq. (11) (39-41). Figure $2 c$ shows the mechanism of nZVI@rEGO formation.

$$
\mathrm{Fe}^{2+}+2 \mathrm{BH}_{4}^{-}+6 \mathrm{H}_{2} \mathrm{O} \rightarrow \mathrm{Fe}^{0}+2 \mathrm{~B}(\mathrm{OH})_{3}+7 \mathrm{H}_{2} \uparrow
$$

\section{Characteristics and analytical methods}

VEGA3/TESCAN-Libusina trida device was employed to provide the scanning electron microscope (SEM) and energy dispersive spectroscopy (EDS) analyses, which show the surface morphology and surface elemental composition of compounds.

X-ray diffraction (XRD) patterns of samples were recorded on an X-ray diffractometer (X'Pert PRO MPD, PANalytical Company) with a CuKa radiation source at $40 \mathrm{kV}$ and $40 \mathrm{~mA}$.

The MB concentration was measured by measuring the absorption of light at a maximum wavelength of 664 $\mathrm{nm}$. For this purpose, first, different concentrations of dye were prepared. Then, their absorption was measured at a maximum wavelength of $664 \mathrm{~nm}$ using a DR 5000 spectrophotometer manufactured by $\mathrm{HACH}$. Then, the calibration curve was obtained by plotting the amount of adsorption in terms of concentration. Finally, by placing the adsorption of the samples in the resulting line equation, the dye concentration was calculated (42). Heidolph MR Hei-Standard magnetic stirrer was also used for mixing the solution. Solution $\mathrm{pH}$ values were adjusted by $0.1 \mathrm{M}$ $\mathrm{HCl}$ and $\mathrm{NaOH}$ solutions. A Metrohm $691 \mathrm{pH}$ meter was used to measure the $\mathrm{pH}$ of solutions. To quench the reaction, Soubh et al method was applied (43).

Batch oxidation experiments

The batch method was employed to perform tests. Briefly, MB solution was placed in a glass flask, then, a certain amount of PS and nZVI@rEGO was added to the solution. Afterwards, the mixture was stirred at 80 rpm. Finally, the concentration of MB was determined at specified time intervals.

To choose the optimum operating conditions, the degradation tests were performed at different ranges of $\mathrm{pH}$ (3-9), nZVI@rEGO dose (0.4-1.6 g L $\left.\mathrm{L}^{-1}\right)$, PS concentration (0.192-0.768 $\left.\mathrm{g} \mathrm{L}^{-1}\right)$, contact time (0-60 minutes), and temperature $\left(5-50^{\circ} \mathrm{C}\right)$. All experiments were conducted with $10 \mathrm{mg} \mathrm{L}^{-1}$ of MB. The removal efficiency of MB was estimated according to Eq. (12).

Removel $(\%)=\left[\left(C_{i}-C_{f}\right) / C_{f}\right] \times 100$

Where $C_{i}$ and $C_{f}$ are the initial and final $\mathrm{MB}$ concentrations, respectively.

Results

Figures $3 \mathrm{a}$ and $3 \mathrm{~b}$ show the XRD patterns of NFG and nZVI@rEGO, respectively. Figures 4a to $4 \mathrm{~b}$ show the SEM images of NFG and nZVI@rEGO, respectively. In order to 
investigate the effect of $\mathrm{pH}$ on the $\mathrm{MB}$ removal efficiency, different values of $\mathrm{pH}(3,5,7$, and 9) were investigated, the results are presented in Figure 5. The effect of different nZVI@rEGO doses (0.4-1.6 $\left.\mathrm{g} \mathrm{L}^{-1}\right)$ with equal intervals of $0.4 \mathrm{~g} \mathrm{~L}^{-1}$ on the removal efficacy of $\mathrm{MB}$ was studied at $\mathrm{MB}$ concentration $=10 \mathrm{mg} \mathrm{L}^{-1}$, PS concentration $=0.288 \mathrm{~g} \mathrm{~L}^{-1}, \mathrm{pH}=3$, and reaction time $=25 \mathrm{~min}$, the results are illustrated in Figure 6. The effect of different PS concentrations (0.192-0.768 $\left.\mathrm{g} \mathrm{L}^{-1}\right)$ on the removal efficiency of $\mathrm{MB}$ was studied at $\mathrm{MB}$ concentration $=10$ mg L ${ }^{-1}, \mathrm{nZVI@rEGO} \mathrm{dose}=1.2 \mathrm{~g} \mathrm{~L}^{-1}, \mathrm{pH}=3$, and reaction time $=25$ minutes, and the results are illustrated in Figure 7. In order to determine the optimal time of the nZVI@ $\mathrm{rEGO/PS}$ process, the experiments were performed again under optimal conditions ( $\mathrm{MB}$ concentration $=10 \mathrm{mg} \mathrm{L}^{-1}$, nZVI@rEGO dose $=1.2 \mathrm{~g} \mathrm{~L}^{-1}$, PS concentration $=0.576 \mathrm{~g}$ $\mathrm{L}^{-1}, \mathrm{pH}=3$, and reaction time $=0-180$ minutes), and the results are shown in Figure 8. The effect of temperature on the performance of nZVI@rEGO/PS and PS processes under optimal conditions $\left(\mathrm{MB}\right.$ concentration $=10 \mathrm{mg} \mathrm{L}^{-1}$, nZVI@rEGO dose $=1.2 \mathrm{~g} \mathrm{~L}^{-1}$, PS concentration $=0.576 \mathrm{~g}$ $\mathrm{L}^{-1}, \mathrm{pH}=3$, and reaction time $=20$ minutes) was studied. For better understanding of the impact of temperature on the removal efficacy of MB by the nZVI@rEGO/PS process, the degradation rate constants were evaluated at temperature of 5,25 , and $50^{\circ} \mathrm{C}$ in the presence and absence of nZVI@rEGO.

\section{Discussion}

Characterization of NFG, EGO, and nZVI@rEGO

As shown in Figure 3a, the XRD patterns of NFG show an intense peak at $2 \theta$ angle of $26^{\circ}$. While it decreased significantly in the XRD patterns of EGO and nZVI@
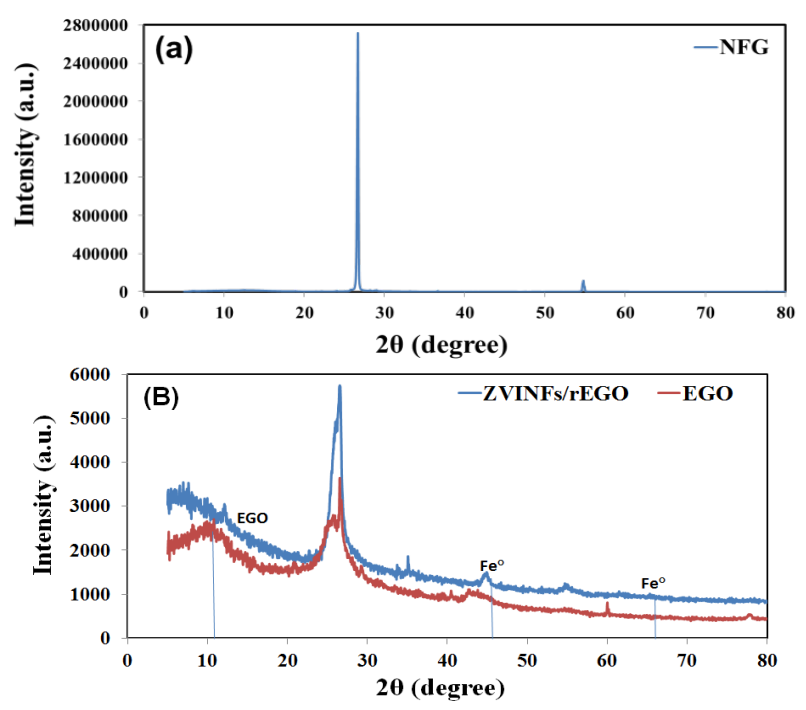

Figure 3. Powder XRD pattern of (a) NFG and (b) EGO and nZVI@rEGO.

rEGO (Figure 3b), this is due to the processes of expansion and oxidation (32). The XRD patterns of nZVI@rEGO confirm the presence of ZVI at $2 \theta$ angles of $44.7^{\circ}$ and $65^{\circ}$, which is consistent with the results of previous studies $(33,44)$.

The SEM images for NFG, EGO, and ZVINFs/rULGO are shown in Figures $4 \mathrm{a}$ to $3 \mathrm{C}$, respectively. As shown in Figure $4 \mathrm{~b}$, the EGO surface became more suitable to carry nanoparticles where the nZVI is placed on the EGO surface in the chain structure with a diameter about 100 $\mathrm{nm}$ (Figure 4c). As shown in Figure 4f, EDS analyses of
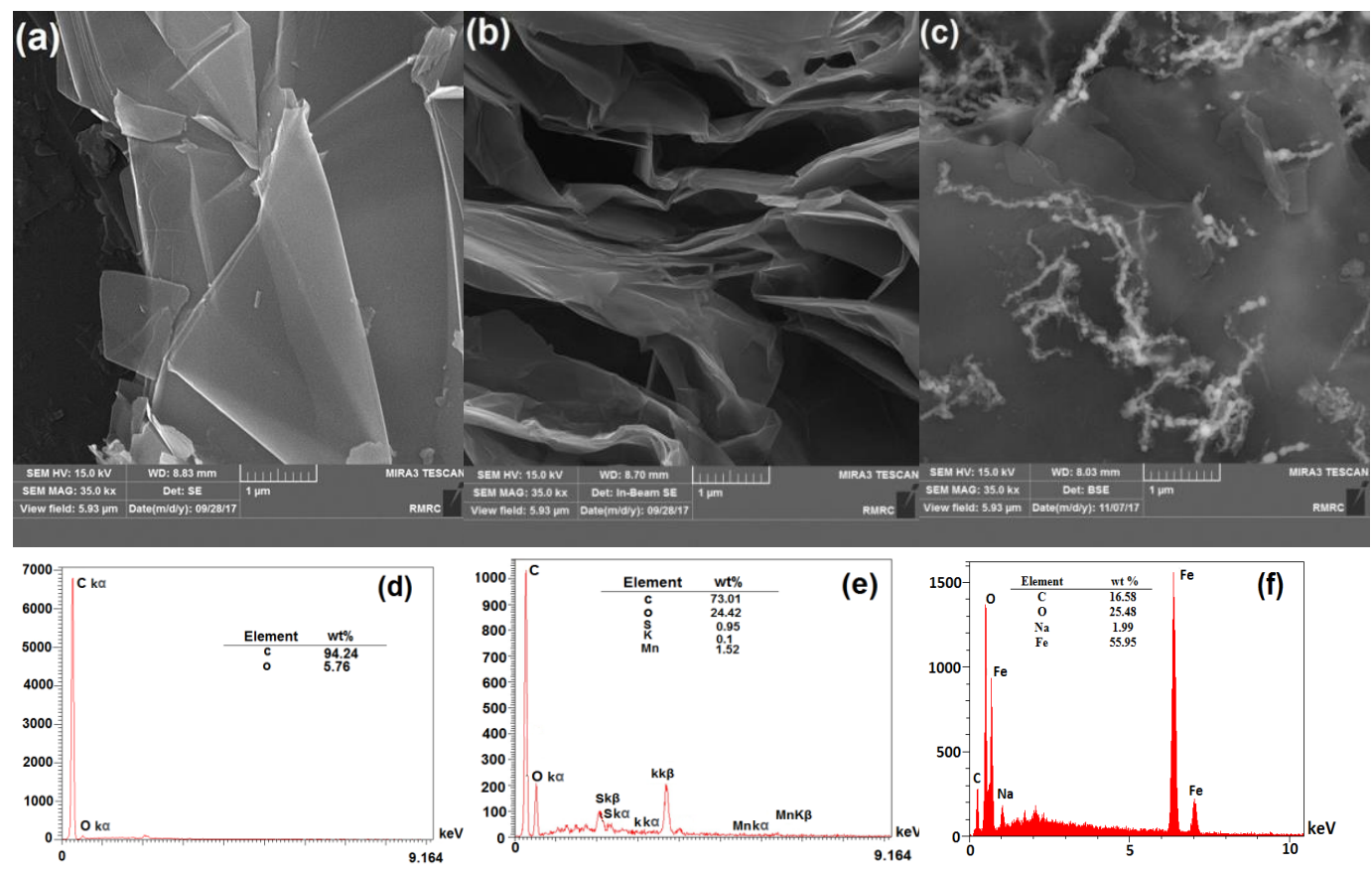

Figure 4. SEM images at 35 KX of (a) NFG, (b) EGO, and (c) nZVI@rEGO, (d) the corresponding EDS spectrum of (e) NFG, (e) EGO, and (f) nZVI@rEGO. 


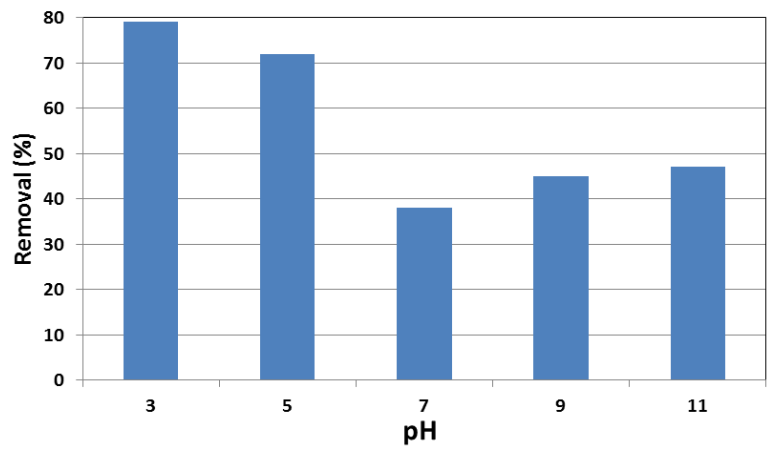

Figure 5. Effect of $\mathrm{pH}$ on the $\mathrm{MB}$ removal under experimental conditions: $\mathrm{MB}$ concentration $=10 \mathrm{mg} \mathrm{L}^{-1}$, $\mathrm{PS}$ concentration = $0.288 \mathrm{~g} \mathrm{~L}^{-1}, \mathrm{nZVI} @ \mathrm{rEGO}$ dose $=1.1 \mathrm{~g} \mathrm{~L}^{-1}$, reaction time = $25 \mathrm{~min}$.

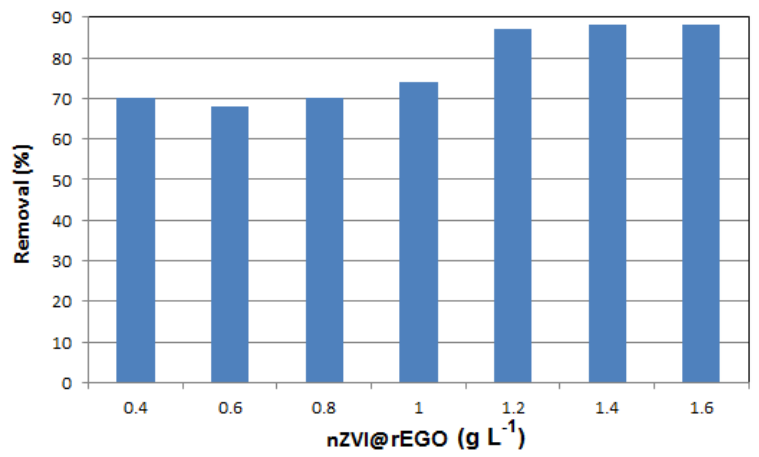

Figure 6. Effect of nZVI@rEGO dosage on the MB removal under experimental conditions: $\mathrm{MB}$ concentration $=10 \mathrm{mg} \mathrm{L}^{-1}$, PS concentration $=0.288 \mathrm{~g} \mathrm{~L}^{-1}, \mathrm{pH}=3$, reaction time $=25 \mathrm{~min}$

nZVI@rEGO indicate the existence of Fe element with an amount greater than $50 \%$, which increases the possibility of its use as a PS activator. The EDS analyses also show an increase in the proportion of oxygen from $5.76 \%$ in NFG (Figure $4 \mathrm{~d}$ ) to $24.42 \%$ in EGO (Figure $4 \mathrm{e}$ ), indicating the success of the oxidation process of EG.

\section{Effect of $\mathrm{pH}$}

The solution $\mathrm{pH}$ has a significant effect on the quantity and type of radicals formed in sulfate radical advanced oxidation processes (SR-AOPs) (45). In the nZVI@ $\mathrm{rEGO} / \mathrm{PS}$ process, $\mathrm{pH}$ has a significant effect on the decomposition of PS through its effect on dissolving nZVI (46). As shown in Figure 5, the removal efficiency of $\mathrm{MB}$ increased by decreasing the solution $\mathrm{pH}$, and the maximum removal efficiency of $\mathrm{MB}$ was $79 \%$ at $\mathrm{pH} 3$. That is because, at acidic conditions, nZVI is decomposed to $\mathrm{Fe}^{+2}$ according to Eq. (1). This led to an increase in activting PS according to Eq. (6).

By increasing $\mathrm{pH}$, the removal efficacy of $\mathrm{MB}$ was decreased to a minimum value at $\mathrm{pH}$ 7. This is due to the formation of iron hydroxide and the reduced presence of iron ions in the solution, according to Eqs. (13-16) (47). By reaching $\mathrm{pH}$ to 9 and 11, the removal efficacy of $\mathrm{MB}$ increased slightly because alkaline conditions contribute to the activation of PS $(48,49)$.

$$
\begin{aligned}
& \mathrm{Fe}^{2+}+\mathrm{H}_{2} \mathrm{O} \rightarrow \mathrm{FeOH}{ }^{+}+\mathrm{H}^{+} \\
& \mathrm{Fe}^{3+}+\mathrm{H}_{2} \mathrm{O} \rightarrow \mathrm{Fe}(\mathrm{OH})^{2+}+\mathrm{H}^{+} \\
& \mathrm{Fe}^{3+}+2 \mathrm{H}_{2} \mathrm{O} \rightarrow \mathrm{Fe}(\mathrm{OH})_{2}^{+}+2 \mathrm{H}^{+} \\
& 2 \mathrm{Fe}^{3+}+2 \mathrm{H}_{2} \mathrm{O} \rightarrow \mathrm{Fe}_{2}(\mathrm{OH})_{2}^{4+}+2 \mathrm{H}^{+}
\end{aligned}
$$

Maximum removal efficiency of anthraquinone dye reactive blue 19 (RB19) using PS/ZVI system has been reported at acidic conditions, i. e. pH 3 (50). In another study, the maximum degradation of nonylphenol by PS/ nZVI-biochar was also reported at pH 3 (24). According to the results obtained from the experiments in this section, $\mathrm{pH} 3$ can be considered as an optimal $\mathrm{pH}$ for the nZVI@rEGO/PS system.

\section{Effect of nZVI@rEGO and PS dose}

As illustrated in Figure 6, the increase of nZVI@rEGO dosage from 0.4 to $1.2 \mathrm{~g} \mathrm{~L}^{-1}$ increased the removal efficacy of $\mathrm{MB}$ from $70 \%$ to $87 \%$. This can be due to the increased activation of PS, according to Eqs. (6), and as a result, increasing the dose of dissolved $\mathrm{Fe}^{2+}$ ions, according to Eqs.

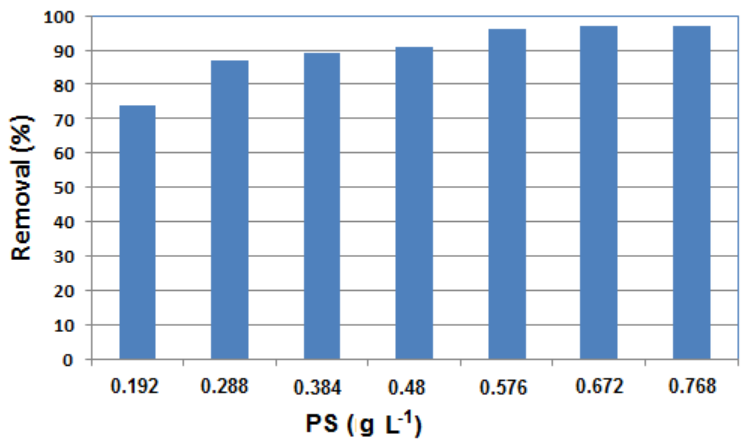

Figure 7. Effect of $\mathrm{PS}$ dose on the MB removal under experimental conditions: $\mathrm{MB}$ concentration = $10 \mathrm{mg} \mathrm{L}^{-1}, \mathrm{nZVI@rEGO} \mathrm{dose} \mathrm{=}$ $1.2 \mathrm{~g} \mathrm{~L}^{-1}, \mathrm{pH}=3$, reaction time $=25 \mathrm{~min}$

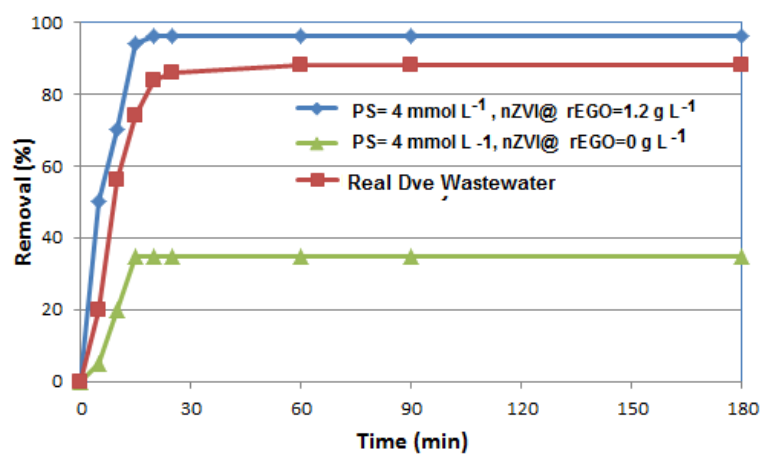

Figure 8. Effect of reaction time on the MB removal under optimal conditions: $\mathrm{MB}$ concentration $=10 \mathrm{mg} \mathrm{L}{ }^{-1}, \mathrm{nZVI@rEGO}$ dose $=$ $1.2 \mathrm{~g} \mathrm{~L}^{-1}$, PS concentration $=0.576 \mathrm{~g} \mathrm{~L}^{-1}, \mathrm{pH}=3$, reaction time $=$ $180 \mathrm{~min}$. 
(1-4). Subsequently, the increase over that dosage did not cause a significant improvement in the removal efficacy of MB. This is because the increasing of concentrations of dissolved $\mathrm{Fe}^{2+}$ ions can quench SR, according to Eq. (16) $(51,52)$.

$$
\mathrm{Fe}^{2+}+\mathrm{SO}_{4}^{--} \rightarrow \mathrm{SO}_{4}^{-}+\mathrm{Fe}^{3+}
$$

In other study, the increasing of ZVI dosage over $0.8 \mathrm{~g}$ $\mathrm{L}^{-1}$ did not significantly improve the decolorization rate of anthraquinone dye reactive blue 19 by the combination of PS and ZVI. Therefore, the nZVI@rEGO dosage of $1.2 \mathrm{~g} \mathrm{~L}^{-1}$ was chosen as the optimal dose for subsequent experiments.

In SR-AOPs, PS dose is one of the effective factors in removing the target contaminant (8). As illustrated in Figure 7, by increasing the PS dose from 0.192 to 0.576 $\mathrm{g} \mathrm{L}^{-1}$, the removal efficiency of MB increased from 74 to $96 \%$. By increasing the PS dose higher than $0.576 \mathrm{~g} \mathrm{~L}^{-1}$, there was no improvement in the removal efficacy of MB. That is because the increase of PS above a certain limit can quench SR, according to Eq. (17) (52). Also, sulfate radicals can react with each other, as a result, they have a quenching effect on the sulfate radical production at high concentration, according to Eq. (18) (15). Le et al have reported that an increase in the initial PS concentration above $20 \mathrm{mM}$ had a negative effect on the removal rate of anthraquinone dye reactive blue 19 in the nZVI/PS system (50). Therefore, the PS dose of $0.576 \mathrm{~g} \mathrm{~L}^{-1}$ was selected to perform the following experiments.

$$
\begin{aligned}
& \mathrm{SO}_{4}{ }^{\cdot-}+\mathrm{S}_{2} \mathrm{O}_{8}{ }^{2-} \rightarrow \mathrm{S}_{2} \mathrm{O}_{8}{ }^{-}+\mathrm{SO}_{4}{ }^{2-} \\
& \mathrm{SO}_{4}{ }^{--}+\mathrm{SO}_{4}{ }^{--} \rightarrow \mathrm{S}_{2} \mathrm{O}_{8}{ }^{2-}
\end{aligned}
$$

\section{Effect of reaction time and temperature}

As can be seen in Figure 8, at reaction time of 20 minutes, the removal efficiency of MB was $96 \%$, after that the removal efficiency of $\mathrm{MB}$ remained almost constant. This can be explained by the fact that the role of divalent iron ions is much greater than trivalent iron in the activation of PS. In the first minutes of the experiment, due to the high concentration of divalent iron ions, the reaction rate was high, which over time and decreasing the concentration of this ion and its conversion to trivalent iron ions (Eq. 16) (36), the process of PS activation also decreased sharply, and as a result, leads to its poor performance. In a study by Hung et al, iron oxide was used as a PS activator to remove $\mathrm{MB}$ dye, and similar results were reported regarding the removal efficiency after the optimal time (1). Thus, the reaction time of 20 minutes was selected as the optimum reaction time. At optimum conditions, the removal efficiency of $\mathrm{MB}$ was $37 \%$ in the absence of activator. Because PS is hydrolyzed alone in the absence of activator, according to Eq. (19) (53).
$\mathrm{S}_{2} \mathrm{O}_{8}{ }^{2-}+2 \mathrm{H}_{2} \mathrm{O} \rightarrow 2 \mathrm{HSO}_{4}{ }^{-}+\mathrm{H}_{2} \mathrm{O}_{2}$

In order to investigate the removal mechanism, some experiments were conducted using PS, EGO, nZVI, and nZVI@rEGO/PS (Figure 9). For this purpose, the effect of PS and nZVI@rEGO on the removal of MB was tested separately, and the related removal efficiencies were significantly lower than that of the nZVI@rEGO/PS system. These results confirmed that the sulfate radical is the main component involving in the removal of MB. In addition, the low removal efficiency obtained using EGO is an indication of its low adsorption efficiency. As shown in Figure 9, only $18.7 \%$ removal of $\mathrm{MB}$ was observed in the ZVI process. The removal of $\mathrm{MB}$ occurred due to the ZVI surface adsorption and reduction.

As shown in Figure 10, by increasing temperature from 25 to $50^{\circ} \mathrm{C}$, the removal efficiency of $\mathrm{MB}$ was increased from $35 \%$ to $51 \%$ by the PS process and from $96 \%$ to $98 \%$ by the nZVI@rEGO/PS process. As heat is considered as an activator of PS that increases removal efficiency, therefore, increasing temperature improved the removal efficiency (54). At temperature of $5^{\circ} \mathrm{C}$, the removal efficiency of $\mathrm{MB}$ by the PS process decreased to $9 \%$. While, there was no significant change in the removal efficiency of $M B$ by the nZVI@rEGO/PS process. This feature makesnZVI@ rEGO/PS process suitable to work at low temperatures.

\section{Removal of $M B$ from real dye wastewater}

The impact of nZVI@rEGO/PS process on dyecontaining wastewater was examined. For this purpose, a series of experiments were performed on the diluted real dye wastewater samples with $\mathrm{MB}\left(10 \mathrm{mg} \mathrm{L}^{-1}\right)$ under optimum conditions. Dye wastewater was obtained from pump station of a tannery wastewater treatment plant. As concentration of $\mathrm{MB}$ in the supplied wastewater was high, for providing comparable concentration of MB (10 $\mathrm{mg} / \mathrm{L})$, supplied wastewater was diluted by distilled water. The characteristics of diluted wastewater were: COD (98 $\left.\mathrm{mg} \mathrm{L}^{-1}\right)$ and $\mathrm{Cl}^{-}\left(440 \mathrm{mg} \mathrm{L}^{-1}\right)$. As shown in Figure 8, the removal efficiency of $\mathrm{MB}$ from real dye wastewater was

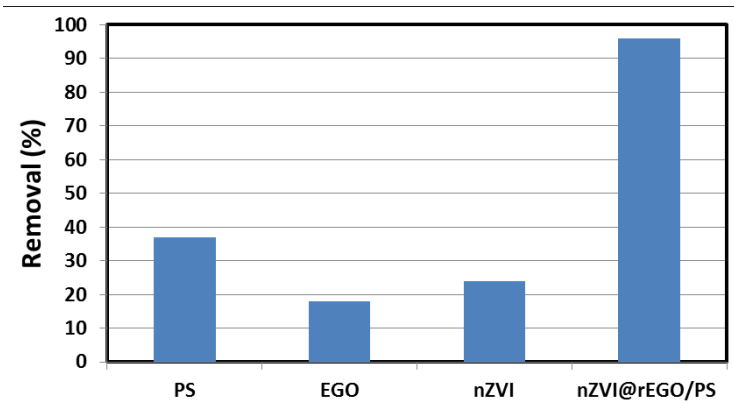

Figure 9. Comparative evaluation of different systems (PS, EGO, nZVI, and nZVI@rEGO/PS) under optimal conditions: MB concentration=10 mg L-1, nZVI@rEGO dose $=1.2 \mathrm{~g} \mathrm{~L}^{-1}, \mathrm{PS}$ concentration $=0.576 \mathrm{~g} \mathrm{~L}^{-1}, \mathrm{pH}=3$, reaction time $=180 \mathrm{~min}$ 


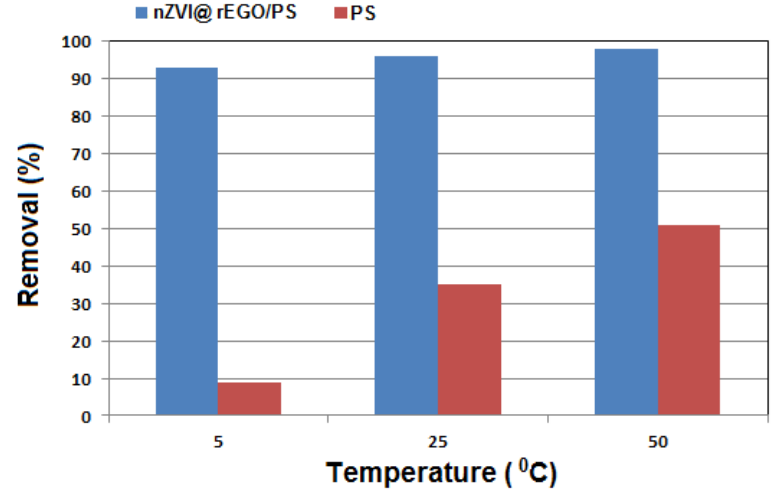

Figure 10. Effect of temperature on the $M B$ removal under optimal conditions: $M B$ concentration $=10 \mathrm{mg} \mathrm{L}^{-1}, \mathrm{nZVI@rEGO}$ dose $=1.2 \mathrm{~g} \mathrm{~L}^{-1}, \mathrm{PS}$ concentration $=0.576 \mathrm{~g} \mathrm{~L}^{-1}, \mathrm{pH}=3$, reaction time $=20 \mathrm{~min}$.

$88 \%$, while the removal efficiency of MB from synthetic wastewater was $96 \%$. This decrease in removal efficiency can be explained by the fact that the real wastewater mainly contains a variety of organic and inorganic contaminants which could decrease contacts with MB $(55,56)$, as well as chloride ion which can scavenge oxidant radicals, and as a result, leads to a decrease in the removal efficiency $(57,58)$

Identification of predominant radicals in nZVI@rEGO/ PS process

To identify the dominant radical species in nZVI@rEGO/ PS process, alcohols were used to quench the hydroxyl and sulfate radicals. Therefore, ethanol (alcohol with alpha hydrogen) as hydroxyl and sulfate radical scavenger and tert-butyl alcohol (TBA) with no alpha hydrogen were used as effective quenching agents for hydroxyl radicals (59). In this study, alcohol (EtOH, TBA) concentration used was 1 $M$. The results clearly showed that aniline degradation was significantly decreased by adding alcohols. As shown in Figure 11, aniline degradation in nZVI@rEGO/PS process without any radical scavenger was $96 \%$. However, in the presence of ethanol (EtOH), only $18 \% \mathrm{MB}$ removal was observed. While in the presence of TBA, the MB removal was $63 \%$. The results revealed that the reaction was completely quenched by adding $\mathrm{EtOH}$ as ${ }^{\circ} \mathrm{OH}$ radical and $\mathrm{SO}_{4}{ }^{--}$radical scavenger, while with the addition of TBA, the removal rate of MB was moderately influenced.

\section{Kinetic modeling}

Kinetics study indicated that nZVI@rEGO/PS decolorization is a pseudo-first-order reaction, which can be expressed according to Eq. (20) (50). As illustrated in Figures 10a and 10b, in the absence of nZVI@rEGO, the degradation rate constants of $\mathrm{MB}$ at temperatures of 5 , 25 , and $50^{\circ} \mathrm{C}$ were $2.5 \times 10^{-3}, 19.5 \times 10^{-3}$, and $29.1 \times 10^{-3}$ $\min ^{-1}$, respectively (Figure 12a). However, in the presence of nZVI@rEGO, the degradation rate constants of $\mathrm{MB}$ at temperatures of 5,25 , and $50^{\circ} \mathrm{C}$ were $96.4 \times 10^{-3}, 135 \times$
$10^{-3}$, and $150.3 \times 10^{-3} \mathrm{~min}^{-1}$, respectively (Figure $12 \mathrm{~b}$ ). In other words, the presence of nZVI@rEGO contributed to strengthening of the degradation rate constants, at above-mentioned temperatures. It has been reported that increasing ferrous concentration from 1 to $4 \mathrm{mM}$ resulted in an increase in the degradation rate constant of Orange $\mathrm{G}$ from 0.04 to $0.12 \mathrm{~min}^{-1}$ in ferrous/persulfate system (60).

$$
\ln \left(\mathrm{C}_{t} / \mathrm{C}_{0}\right)=-k t
$$

The Arrhenius equation (Eq. 21) was used to evaluate the activation energy of reaction at above-mentioned temperatures (61).

$$
\ln k=\ln A-E_{a} / R T
$$

Where $k$ is the pseudo first-order rate constant $\left(\mathrm{min}^{-1}\right), A$ is the pre-exponential factor $\left(\mathrm{min}^{-1}\right), E_{a}$ is the activation energy $\left(\mathrm{kJ} \mathrm{mol}^{-1}\right), R$ is the universal gas constant $(0.0083 \mathrm{~kJ}$ $\mathrm{mol}^{-1}$ ), and $T$ is the solution temperature (K). It could be observed that there is a strong linear relationship between lnk and 1/T (Figure 13), the presence of nZVI@rEGO decreased the activation energies of $\mathrm{MB}$ removal from 45.9 to $8.32 \mathrm{~kJ} \mathrm{~mol}^{-1}$ (Table 1). In other words, it caused 5.5 times decrease in $\mathrm{E}_{\mathrm{a}}$ of $\mathrm{MB}$ removal. This decline in $\mathrm{E}_{\mathrm{a}}$ is attributed to the activation provided by the nZVI@ rEGO of PS. In other words, generation of SR at this level need less $\mathrm{E}_{\mathrm{a}}$, and as a result, the existence of nZVI@rEGO with PS together in the solution (62). In other studies, the activation energy was decreased from 120.4 to 36.1 $\mathrm{kJ} \mathrm{mol}{ }^{-1}$ using $\mathrm{Fe}^{0}$ as an activator of PS for degradation of acetaminophen (15), and the activation energy was $98 \mathrm{~kJ}$ $\mathrm{mol}^{-1}$ using ZVI as an activator of PS for decolorization of anthraquinone dye reactive blue 19 (50).

\section{Conclusion}

This study investigated the removal efficiency of $\mathrm{MB}$ in aqueous solutions by the nZVI@rEGO/PS process. The

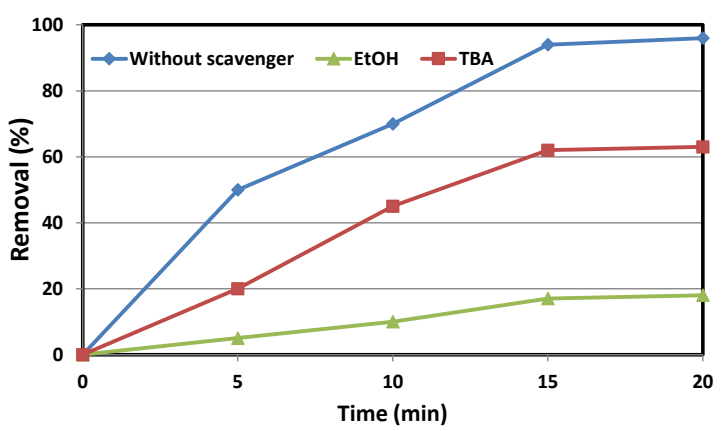

Figure 11. Effect of EtOH and TBA as radical scavengers on the MB removal under optimal conditions in the nZVI@rEGO/PS process: $\mathrm{MB}$ concentration $=10 \mathrm{mg} \mathrm{L}^{-1}, \mathrm{nZVI} @ \mathrm{rEGO}$ dose $=1.2 \mathrm{~g}$ $\mathrm{L}^{-1}, \mathrm{PS}$ concentration $=0.576 \mathrm{~g} \mathrm{~L}^{-1}, \mathrm{pH}=3$, reaction time $=20 \mathrm{~min}$ 

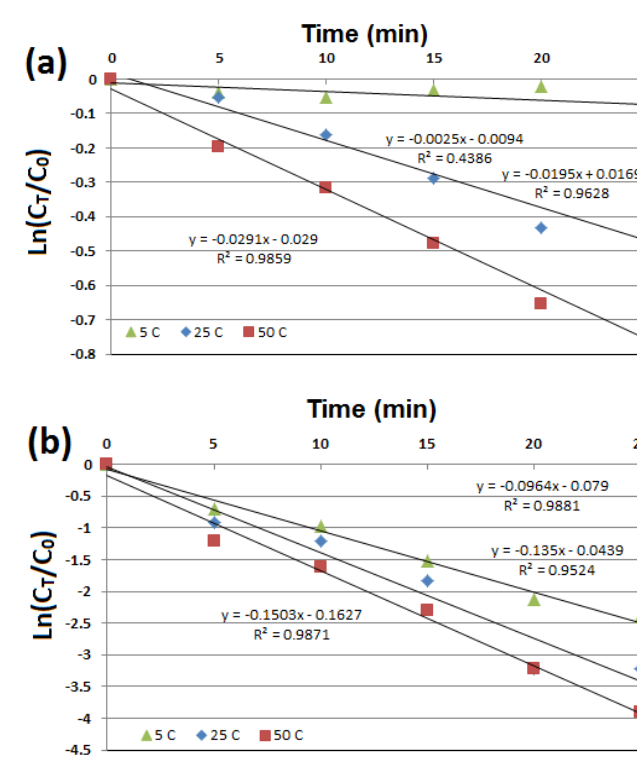

Figure 12. Effect of temperature on the removal rate of $M B(a)$ in the absence of nZVI@rEGO and (b) in the presence of nZVI@ rEGO, under optimal conditions: $M B$ concentration $=10 \mathrm{mg} \mathrm{L}^{-1}$, $\mathrm{nZVI@rEGO} \mathrm{dose}=1.2 \mathrm{~g} \mathrm{~L}^{-1}, \mathrm{PS}$ concentration $=0.576 \mathrm{~g} \mathrm{~L}^{-1}, \mathrm{pH}$ $=3$, reaction time $=20 \mathrm{~min}$

experiments proved the effectiveness of the use of nZVI@ rEGO as an acivator of PS for removal of MB. EGO was proposed as an efficient bed for the immobilization of nZVI.EDS analysis of nZVI@rEGO indicates the existence of Fe element to an amount greater than 50\%. The XRD patterns of nZVI@rEGO confirmed the presence of ZVI at the $2 \theta$ angles of $44.7^{\circ}$ and $65^{\circ}$. The addition of $1.2 \mathrm{~g} \mathrm{~L}^{-1}$ of nZVI@rEGO at temperatures of 5, 25, and $50^{\circ} \mathrm{C}$ led to $38.56,6.92$, and 5.16 times, respectively, increase in degradation rate of MB. The presence of nZVI@rEGO decreased the activation energies of $\mathrm{MB}$ degradation from 45.9 to $8.3 \mathrm{~kJ} \mathrm{~mol}^{-1}$. In other words, it caused 5.5 times decrease in $\mathrm{E}_{\mathrm{a}}$ of $\mathrm{MB}$ removal.

Acknowledgments

The authors would like to thank the Nanotechnology Research Center of Graduate Faculty of Environment, University of Tehran, for supporting this project.

\section{Ethical issues}

The authors certify that this this manuscript is the original work of the authors, all data collected during the study are presented in this manuscript, and no data from the study has been or will be published elsewhere separately.

\section{Competing interests}

The authors declare that they have no conflict of interests.

\section{Author's contributions}

The tests were conceived and prepared by AMS, and data analysis and writing of the manuscript were performed by all authors.

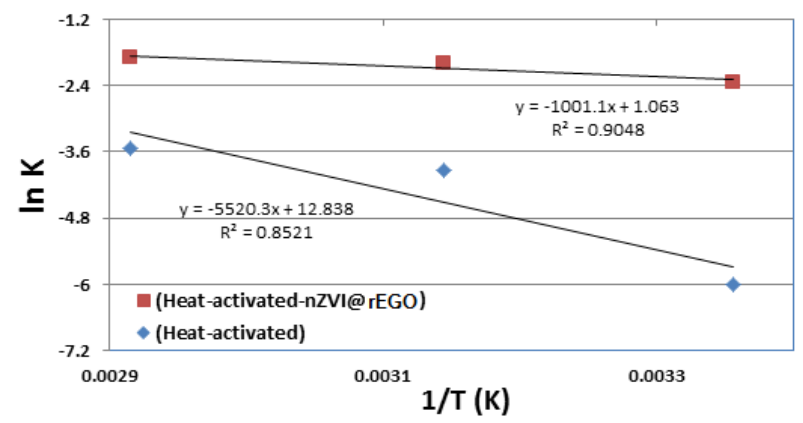

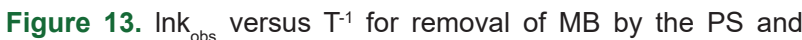
nZVI@rEGO/PS systems according to Arrhenius equation, under optimal conditions: MB concentration = $10 \mathrm{mg} \mathrm{L}^{-1}, \mathrm{nZVI@rEGO}$ dose $=1.2 \mathrm{~g} \mathrm{~L}^{-1}$, PS concentration $=0.576 \mathrm{~g} \mathrm{~L}^{-1}, \mathrm{pH}=3$, reaction time $=20 \mathrm{~min}$

Table 1. The parameters calculated at different temperatures

\begin{tabular}{|c|c|c|c|c|c|c|}
\hline \multirow{2}{*}{ Temperature } & \multicolumn{3}{|c|}{ nZVI@rEGO/PS } & \multicolumn{3}{|c|}{ Heat-activated PS } \\
\hline & 298K & $318 \mathrm{~K}$ & $343 K$ & 298K & $318 K$ & $343 K$ \\
\hline $\mathrm{K}_{1}, 10^{-3} \mathrm{~min}^{-1}$ & 29.7 & 1 & 4.4 & 96.4 & 135 & 150.3 \\
\hline $\mathrm{R}\left(\mathrm{kJ} \mathrm{mol}{ }^{-1}\right)$ & \multicolumn{3}{|c|}{0.0083} & \multicolumn{3}{|c|}{0.0083} \\
\hline Lnk $=\ln A-E_{a} / R T$ & \multicolumn{3}{|c|}{$Y=1001.1 X+1.063$} & \multicolumn{3}{|c|}{$Y=5520.3 X+12.838$} \\
\hline $\mathrm{E}_{\mathrm{a}}\left(\mathrm{kJ} / \mathrm{mol}^{-1}\right)$ & \multicolumn{3}{|c|}{8.32} & \multicolumn{3}{|c|}{45.9} \\
\hline$A\left(\min ^{-1}\right)$ & \multicolumn{3}{|c|}{2.89} & \multicolumn{3}{|c|}{376246.578} \\
\hline
\end{tabular}

\section{References}

1. Hung CM, Chen CW, Liu YY, Dong CD. Decolorization of methylene blue by persulfate activated with $\mathrm{FeO}$ magnetic particles. Water Environ Res 2016; 88(8): 675-86. doi: 10.21 75/106143016x14609975746848.

2. Xiao X, Zhang F, Feng Z, Deng S, Wang Y. Adsorptive removal and kinetics of methylene blue from aqueous solution using NiO/MCM-41 composite. Physica E Low Dimens Syst Nanostruct 2015; 65: 4-12. doi: 10.1016/j. physe.2014.08.006.

3. Alene AN, Abate GY, Habte AT. Bioadsorption of basic blue dye from aqueous solution onto raw and modified waste ash as economical alternative bioadsorbent. J Chem 2020; 2020: 8746035. doi: 10.1155/2020/8746035.

4. Royer B, Cardoso NF, Lima EC, Vaghetti JC, Simon NM, Calvete T, et al. Applications of Brazilian pine-fruit shell in natural and carbonized forms as adsorbents to removal of methylene blue from aqueous solutions--kinetic and equilibrium study. J Hazard Mater 2009; 164(2-3): 1213-22. doi: 10.1016/j.jhazmat.2008.09.028.

5. Ding F, Xie Y, Peng W, Peng YK. Measuring the bioactivity and molecular conformation of typically globular proteins with phenothiazine-derived methylene blue in solid and in solution: a comparative study using photochemistry and computational chemistry. J Photochem Photobiol B 2016; 158: 69-80. doi: 10.1016/j.jphotobiol.2016.02.029.

6. Zawadzki P. Decolorisation of methylene blue with sodium persulfate activated with visible light in the presence of glucose and sucrose. Water Air Soil Pollut 2019; 230(12): 313. doi: 10.1007/s11270-019-4372-x.

7. Zhen G, Lu X, Zhao Y, Chai X, Niu D. Enhanced dewaterability of sewage sludge in the presence of $\mathrm{Fe}(\mathrm{II})$ - 
activated persulfate oxidation. Bioresour Technol 2012; 116: 259-65. doi: 10.1016/j.biortech.2012.01.170.

8. Abu Amr SS, Aziz HA, Adlan MN, Bashir MJ. Pretreatment of stabilized leachate using ozone/persulfate oxidation process. Chem Eng J 2013; 221: 492-9. doi: 10.1016/j. cej.2013.02.038.

9. Soubh A, Mokhtarani N. The post treatment of composting leachate with a combination of ozone and persulfate oxidation processes. RSC Adv 2016; 6(80): 76113-22. doi: 10.1039/c6ra09539a.

10. Anipsitakis GP, Dionysiou DD, Gonzalez MA. Cobaltmediated activation of peroxymonosulfate and sulfate radical attack on phenolic compounds. implications of chloride ions. Environ Sci Technol 2006; 40(3): 1000-7. doi: 10.1021/es050634b.

11. Soubh AM. Assessment of steel slag as a persulfate activator for treatment of landfill leachate. Open Access Journal of Waste Management \& Xenobiotics 2019; 2(3): 1-6. doi: 10.23880/oajwx-16000125.

12. Soubh AM, Baghdadi M, Abdoli MA, Aminzadeh B. Zerovalent iron nanofibers (ZVINFs) immobilized on the surface of reduced ultra-large graphene oxide (rULGO) as a persulfate activator for treatment of landfill leachate. J Environ Chem Eng 2018; 6(5): 6568-79. doi: 10.1016/j. jece.2018.10.011.

13. Graça CA, Fugita LT, de Velosa AC, Teixeira A. Amicarbazone degradation promoted by ZVI-activated persulfate: study of relevant variables for practical application. Environ Sci Pollut Res Int 2018; 25(6): 547483. doi: 10.1007/s11356-017-0862-9.

14. Meserghani M, Nikaeen M, Jonidi Jafari A, Dehghani MH, Bina B. Amoxicillin degradation with electro-persulfate combined with $\mathrm{H} 2 \mathrm{O} 2$ from aqueous solution using response surface methodology. Environ Health Eng Manag 2020; 7(3): 209-16. doi: 10.34172/ehem.2020.24.

15. Deng J, Shao Y, Gao N, Deng Y, Tan C, Zhou S. Zero-valent iron/persulfate(Fe0/PS) oxidation acetaminophen in water. Int J Environ Sci Technol 2014; 11(4): 881-90. doi: 10.1007/ s13762-013-0284-2.

16. Zhao J, Zhang Y, Quan X, Chen S. Enhanced oxidation of 4-chlorophenol using sulfate radicals generated from zerovalent iron and peroxydisulfate at ambient temperature. Sep Purif Technol 2010; 71(3): 302-7. doi: 10.1016/j. seppur.2009.12.010

17. Crane RA, Scott TB. Nanoscale zero-valent iron: Future prospects for an emerging water treatment technology. J Hazard Mater 2012; 211-212: 112-25. doi: 10.1016/j. jhazmat.2011.11.073.

18. Shih YH, Tai YT. Reaction of decabrominated diphenyl ether by zerovalent iron nanoparticles. Chemosphere 2010; 78(10): 1200-6. doi: 10.1016/j.chemosphere.2009.12.061.

19. Zhan J, Zheng T, Piringer G, Day C, McPherson GL, Lu $\mathrm{Y}$, et al. Transport characteristics of nanoscale functional zerovalent iron/silica composites for in situ remediation of trichloroethylene. Environ Sci Technol 2008; 42(23): 88716. doi: 10.1021/es800387p.

20. Phenrat T, Saleh N, Sirk K, Tilton RD, Lowry GV. Aggregation and sedimentation of aqueous nanoscale zerovalent iron dispersions. Environ Sci Technol 2007; 41(1): 284-90. doi: 10.1021/es061349a.

21. Pasinszki T, Krebsz M. Synthesis and application of zero- valent iron nanoparticles in water treatment, environmental remediation, catalysis, and their biological effects. Nanomaterials (Basel) 2020; 10(5):917. doi: 10.3390/ nano10050917.

22. Li A, Tai C, Zhao Z, Wang Y, Zhang Q, Jiang G, et al. Debromination of decabrominated diphenyl ether by resin-bound iron nanoparticles. Environ Sci Technol 2007; 41(19): 6841-6. doi: 10.1021/es070769c.

23. Zhang X, Lin S, Chen Z, Megharaj M, Naidu R. Kaolinitesupported nanoscale zero-valent iron for removal of $\mathrm{Pb} 2+$ from aqueous solution: reactivity, characterization and mechanism. Water Res 2011; 45(11): 3481-8. doi: 10.1016/j. watres.2011.04.010.

24. Hussain I, Li M, Zhang Y, Li Y, Huang S, Du X, et al. Insights into the mechanism of persulfate activation with $\mathrm{nZVI} / \mathrm{BC}$ nanocomposite for the degradation of nonylphenol. Chem Eng J 2017; 311: 163-72. doi: 10.1016/j.cej.2016.11.085.

25. Zhu BW, Lim TT, Feng J. Reductive dechlorination of 1,2,4-trichlorobenzene with palladized nanoscale $\mathrm{Fe}$ (zero-valent) particles supported on chitosan and silica. Chemosphere 2006; 65(7): 1137-45. doi: 10.1016/j. chemosphere.2006.04.012.

26. Wang Y, Sun H, Duan X, Ang HM, Tadé MO, Wang S. A new magnetic nano zero-valent iron encapsulated in carbon spheres for oxidative degradation of phenol. Appl Catal B Environ 2015; 172-173: 73-81. doi: 10.1016/j. apcatb.2015.02.016.

27. Jabeen H, Chandra V, Jung S, Lee JW, Kim KS, Kim SB. Enhanced $\mathrm{Cr}$ (vi) removal using iron nanoparticle decorated graphene. Nanoscale 2011; 3(9): 3583-5. doi: 10.1039/ clnr10549c.

28. Adlnasab L, Djafarzadeh N, Maghsodi A. A new magnetic bio-sorbent for arsenate removal from the contaminated water: characterization, isotherms, and kinetics. Environ Health Eng Manag 2020; 7(1): 49-58. doi: 10.34172/ ehem.2020.07.

29. Wang J, Chen B, Xing B. Wrinkles and folds of activated graphene nanosheets as fast and efficient adsorptive sites for hydrophobic organic contaminants. Environ Sci Technol 2016; 50(7): 3798-808. doi: 10.1021/acs.est.5b04865.

30. Wang J, Chen B. Adsorption and coadsorption of organic pollutants and a heavy metal by graphene oxide and reduced graphene materials. Chem Eng J 2015; 281: 379-88. doi: 10.1016/j.cej.2015.06.102.

31. Pu S, Deng D, Wang K, Wang M, Zhang Y, Shangguan $\mathrm{L}$, et al. Optimizing the removal of nitrate from aqueous solutions via reduced graphite oxide-supported nZVI: synthesis, characterization, kinetics, and reduction mechanism. Environ Sci Pollut Res Int 2019; 26(4): 393245. doi: 10.1007/s11356-018-3813-1.

32. Dong L, Chen Z, Lin S, Wang K, Ma C, Lu H. Reactivitycontrolled preparation of ultralarge graphene oxide by chemical expansion of graphite. Chem Mater 2017; 29(2): 564-72. doi: 10.1021/acs.chemmater.6b03748.

33. Fan M, Li T, Hu J, Cao R, Wu Q, Wei X, et al. Synthesis and characterization of reduced graphene oxide-supported nanoscale zero-valent iron (nZVI/rGO) composites used for $\mathrm{Pb}(\mathrm{II})$ removal. Materials (Basel) 2016; 9(8):687. doi: 10.3390/ma9080687.

34. Wang C, Luo $\mathrm{H}$, Zhang $\mathrm{Z}$, Wu Y, Zhang J, Chen S. Removal of $\mathrm{As}(\mathrm{III})$ and $\mathrm{As}(\mathrm{V})$ from aqueous solutions 
using nanoscale zero valent iron-reduced graphite oxide modified composites. J Hazard Mater 2014; 268: 124-31. doi: 10.1016/j.jhazmat.2014.01.009.

35. Li J, Chen C, Zhu K, Wang X. Nanoscale zero-valent iron particles modified on reduced graphene oxides using a plasma technique for Cd(II) removal. J Taiwan Inst Chem Eng 2016; 59: 389-94. doi: 10.1016/j.jtice.2015.09.010.

36. Ahmad A, Gu X, Li L, Lv S, Xu Y, Guo X. Efficient degradation of trichloroethylene in water using persulfate activated by reduced graphene oxide-iron nanocomposite. Environ Sci Pollut Res Int 2015; 22(22): 17876-85. doi: 10.1007/s11356-015-5034-1.

37. Mittal J, Konno H, Inagaki M. Synthesis of graphite intercalation compounds with CrVI compounds using $\mathrm{CrO} 3$ and $\mathrm{HCl}$ at room temperature. Synth Met 1998; 96(2): 103-8. doi: 10.1016/S0379-6779(98)00070-8.

38. Skowroński JM. Exfoliation of graphite-CrO3 intercalation compounds in hydrogen peroxide solution. J Mater Sci 1988; 23(6): 2243-6. doi: 10.1007/bf01115794.

39. Li Y, Zhang Y, Li J, Zheng X. Enhanced removal of pentachlorophenol by a novel composite: nanoscale zero valent iron immobilized on organobentonite. Environ Pollut 2011; 159(12): 3744-9. doi: 10.1016/j.envpol.2011.07.016.

40. Prema P, Selvarani M. Inactivation of bacteria using chemically fabricated zerovalent iron nanoparticles. Int Res J Pharm Sci 2012; 3(1): 27-31.

41. Selvarani M, Prema P. Removal of toxic metal hexavalent chromium [cr(vi)] from aqueous solution using starchstabilized nanoscale zerovalent iron as adsorbent: equilibrium and kinetics. Int J Environ Sci 2012; 2(4): 196275. doi: 10.6088/ijes.00202030080.

42. Zhao L, Yang S, Wang L, Shi C, Huo M, Li Y. Rapid and simple spectrophotometric determination of persulfate in water by microwave assisted decolorization of Methylene Blue. J Environ Sci 2015; 31: 235-9. doi: 10.1016/j. jes.2014.09.036.

43. Soubh AM, Baghdadi M, Abdoli MA, Aminzadeh B. Activation of persulfate using an industrial iron-rich sludge as an efficient nanocatalyst for landfill leachate treatment. Catalysts 2018; 8(5): 218. doi: 10.3390/catal8050218.

44. Hoch LB, Mack EJ, Hydutsky BW, Hershman JM, Skluzacek JM, Mallouk TE. Carbothermal synthesis of carbonsupported nanoscale zero-valent iron particles for the remediation of hexavalent chromium. Environ Sci Technol 2008; 42(7): 2600-5. doi: 10.1021/es702589u.

45. Mokhtarani N, Khodabakhshi S, Ayati B. Optimization of photocatalytic post-treatment of composting leachate using UV/TiO2. Desalin Water Treat 2016; 57(47): 22232-43. doi: 10.1080/19443994.2015.1130652.

46. Ahmad A, Gu X, Li L, Lu S, Xu Y, Guo X. Effects of pH and anions on the generation of reactive oxygen species (ROS) in nZVI-rGo-activated persulfate system. Water Air Soil Pollut 2015; 226(11): 369. doi: 10.1007/s11270-015-2635-8.

47. Govindan K, Raja M, Maheshwari SU, Noel M. Analysis and understanding of amido black 10B dye degradation in aqueous solution by electrocoagulation with the conventional oxidants peroxomonosulfate, peroxodisulfate and hydrogen peroxide. Environ Sci Water Res Technol 2015; 1(1): 108-19. doi: 10.1039/c4ew00030g.

48. Furman OS, Teel AL, Watts RJ. Mechanism of base activation of persulfate. Environ Sci Technol 2010; 44(16): 6423-8. doi: 10.1021/es1013714.

49. Liang C, Guo YY. Remediation of diesel-contaminated soils using persulfate under alkaline condition. Water Air Soil Pollut 2012; 223(7): 4605-14. doi: 10.1007/s11270-0121221-6.

50. Le C, Wu JH, Li P, Wang X, Zhu NW, Wu PX, et al. Decolorization of anthraquinone dye Reactive Blue 19 by the combination of persulfate and zero-valent iron. Water Sci Technol 2011; 64(3): 754-9. doi: 10.2166/wst.2011.708.

51. Monteagudo JM, Durán A, González R, Expósito AJ. In situ chemical oxidation of carbamazepine solutions using persulfate simultaneously activated by heat energy, UV light, $\mathrm{Fe} 2+$ ions, and $\mathrm{H} 2 \mathrm{O} 2$. Appl Catal B Environ 2015; 176-177: 120-9. doi: 10.1016/j.apcatb.2015.03.055.

52. Yang S, Yang X, Shao X, Niu R, Wang L. Activated carbon catalyzed persulfate oxidation of Azo dye acid orange 7 at ambient temperature. J Hazard Mater 2011; 186(1): 659-66. doi: 10.1016/j.jhazmat.2010.11.057.

53. House DA. Kinetics and mechanism of oxidations by peroxydisulfate. Chem Rev 1962; 62(3): 185-203. doi: $10.1021 / \mathrm{cr} 60217 \mathrm{a} 001$.

54. Liang C, Wang ZS, Bruell CJ. Influence of $\mathrm{pH}$ on persulfate oxidation of TCE at ambient temperatures. Chemosphere 2007; 66(1): 106-13. doi: 10.1016/j. chemosphere.2006.05.026.

55. Moussavi G, Mahdavianpour M. The selective direct oxidation of ammonium in the contaminated water to nitrogen gas using the chemical-less VUV photochemical continuous-flow reactor. Chem Eng J 2016; 295: 57-63. doi: 10.1016/j.cej.2016.03.035.

56. Dutta K, Mukhopadhyay S, Bhattacharjee S, Chaudhuri B. Chemical oxidation of methylene blue using a Fenton-like reaction. J Hazard Mater 2001; 84(1): 57-71. doi: 10.1016/ s0304-3894(01)00202-3.

57. Liao CH, Kang SF, Wu FA. Hydroxyl radical scavenging role of chloride and bicarbonate ions in the $\mathrm{H} 2 \mathrm{O} 2 / \mathrm{UV}$ process. Chemosphere 2001; 44(5): 1193-200. doi: 10.1016/s00456535(00)00278-2.

58. Mahdavianpour M, Ildari S, Ebrahimi M, Moslemzadeh M. Decolorization and mineralization of methylene blue in aqueous solutions by persulfate/ $\mathrm{Fe} 2+$ process. J Water Chem Technol 2020; 42(4): 244-51. doi: 10.3103/ S1063455X20040098.

59. Hussain I, Zhang Y, Huang S. Degradation of aniline with zero-valent iron as an activator of persulfate in aqueous solution. RSC Adv 2014; 4(7): 3502-11. doi: 10.1039/ c3ra43364a.

60. Xu XR, Li XZ. Degradation of azo dye Orange $G$ in aqueous solutions by persulfate with ferrous ion. Sep Purif Technol 2010; 72(1): 105-11. doi: 10.1016/j.seppur.2010.01.012.

61. Hasan M, Ahmad AL, Hameed BH. Adsorption of reactive dye onto cross-linked chitosan/oil palm ash composite beads. Chem Eng J 2008; 136(2-3): 164-72. doi: 10.1016/j. cej.2007.03.038.

62. Oh SY, Kim HW, Park JM, Park HS, Yoon C. Oxidation of polyvinyl alcohol by persulfate activated with heat, $\mathrm{Fe} 2+$, and zero-valent iron. J Hazard Mater 2009; 168(1): 346-51. doi: 10.1016/j.jhazmat.2009.02.065. 